\title{
Climate Change and International Conflict: How Climate Change's Impact on the Nile Affects Egypt-Ethiopia Conflict
}

\section{Rafsyanjani Mohammad}

Universitas Airlangga, Indonesia

Email: rafsyanjani.mohammad-2019@fisip.unair.ac.id

\begin{abstract}
This article aims to explain the influence of climate change on the international conflict between Egypt and Ethiopia. The climate change phenomenon was already felt in various parts of the world, but its impact will be more significant if it hits hotspot areas such as the Nile. Therefore, the author will first describe a literature review of relations between climate change and international conflict. Second, the article will explain how the climate change phenomenon in the Nile is resulting in some security risks, especially toward Egypt. This research concludes that the climate change phenomenon in the Nile can exacerbate the conflict escalation between Egypt and Ethiopia and security threats in Egyptian water, food, and the economy due to climate change. However, many who doubt the possibility of armed conflict, Nile's condition as one of the hotspots of climate change and the absence of comprehensive international river management make all options still counted and must be undertaken cautiously.
\end{abstract}

Keywords: climate change, international conflict, Egypt, Ethiopia, Nile

\begin{abstract}
Abstrak
Artikel ini bertujuan untuk memahami dan menjelaskan pengaruh perubahan iklim terhadap konflik internasional yang terjadi antara Mesir dan Ethiopia. Fenomena perubahan iklim sudah dapat dirasakan di berbagai belahan dunia namun dampaknya akan semakin signifikan apabila melanda daerahdaerah hotspot seperti kawasan Nil. Oleh karena itu, pertama, penulis akan memaparkan tinjauan literatur mengenai hubungan antara perubahan iklim
\end{abstract}


dengan konflik internasional. Kedua, artikel ini akan menjelaskan bagaimana perubahan iklim di Sungai Nil menghadirkan berbagai bentuk ancaman keamanan khususnya terhadap Mesir. Penulis kemudian berargumen bahwa fenomena perubahan iklim di Sungai Nil dapat mendorong terjadinya eskalasi konflik antara Mesir dan Ethiopia seiring dengan keberadaan ancaman di sektor air, pangan dan ekonomi Mesir sebagai akibat dari perubahan iklim. Meskipun banyak pihak meragukan terjadinya perang, namun melihat realita yang ada di mana daerah merupakan salah satu hotspot perubahan iklim dan ditambah dengan ketiadaan manajemen sungai internasional yang komprehensif, maka segala kemungkinan yang ada pun masih dapat terjadi dan harus diperhatikan dengan seksama.

Kata Kunci: perubahan iklim, konflik internasional, Mesir, Ethiopia, Nil

\section{INTRODUCTION}

Current trends in global climate change still seem to indicate distressing conditions. Intergovernmental Panel on Climate Change (2018) released a special report that estimates that global warming will reach $1.5^{\circ} \mathrm{C}$ in 2030-2052 if the trend continues at its current speed. However, it is predicted that it will not reach $2^{\circ} \mathrm{C}$ soon. Global warming at $1.5^{\circ} \mathrm{C}$ is still considered significant damage to natural and human systems than current conditions. United Nations Climate Change Secretariat (2019) explains that climate change will escalate climate risks and hazards, especially extreme weather, flooding, changes in precipitation rate, drought, increasing temperatures, and rising sea levels. The increasing frequency of climate hazards above has resulted in various vulnerabilities, especially in water, agriculture, and health sectors threatening the sustainability of future human socio-economic conditions.

In addition to threatening socio-economic conditions, climate change is also suspected of having relations with the security situation, especially in its capacity as a driving force of conflict. Although it is not a direct causal factor, climate change can still affect security conditions in various ways, such as influencing resource availability, affecting how humans access these resources, regulating population movements, changing economic conditions and 
determining power relations (Levine et al., 2014)the goal of so many concerned about crises, poverty, climate change and conflict, is often presented as a technical challenge - that is, technical interventions, ranging from stronger schools and higher dams to more irrigation and drought-resistant seeds, are often presented as the 'solution' to the resilience 'problem'. The increasing consensus that climate change is a threat to the development of poorer nations and a cause of humanitarian crises has ensured that climate change concerns are at the centre of recent discussions on resilience. This has also contributed to the belief that supporting resilience requires a broad, multi-disciplinary approach, and that resilience may even provide a conceptual umbrella under which experts from different disciplines can find a common language (e.g. Davies et al., 2013. The whole situation can trigger the acceleration of tension, riots, and conflicts at local, national, or even international levels.

One of the regions affected famously by climate change is the Nile in Africa. The Nile is a vital river for countries located along the basins, especially for downstream areas such as Egypt, where 97 percent of its national water needs come from the Nile (Newman, 2019). Climate change is predicted to cause Nile's water flow patterns challenging to predict, and even in the future, it can reduce the river's capacity by as much as 25 percent (Schlanger, 2019).

The geographical position of the Nile as an international river potentially brings up potential dimensions of conflict between countries amid the threatened capacity of the river due to climate change effects. Indeed, international disputes related to the Nile's management have long occurred before the river is affected by current climate change. However, the effects of climate change on the Nile must also be considered a factor in the regional security constellation between Nile basin countries. This paper will focus on a research question about how climate change factors affect international conflict circumstances among the Nile basin countries? To answer this question, the author will limit the research's focus on the only conflict between Egypt and Ethiopia without marginalizing the potential for broader conflict outside the two countries. The author's initial statement affirmed the impact of climate change on the Nile ecosystem in one way or another had 
influenced international conflicts circumstance, especially between Egypt and Ethiopia.

\section{LITERATURE REVIEW: CLIMATE} CHANGE AND INTERNATIONAL CONFLICT

Initially, the International Relations (IR) study looks at the environment only as one of the components that constitute the national power. However, along with the increasing environmental degradation due to climate change, IR scholars began to expand the studies' scope on environmental issues, including in security studies. Homer-Dixon (in Vogler, 2014) states the link between environment (climate change) and conflict (security) issues is mainly caused by the expansion and deepening of traditional security concepts that have begun to accommodate human-centered security rather than merely ends at traditional military-oriented security.

Tyler H. Lippert states in his dissertation NATO, Climate Change, and International Security that one of the critical aspects of climate security is the cross-border and global dimensions of climate change threats. This argument is based on the "global" nature of the climate system. The socio-environmental impacts of climate change in one region can lead to the cross-border consequences endured by other parts elsewhere (Lippert, 2016) I apply the International Risk Governance Council's (IRGC.

The "international" nature of climate change's security impacts is also featured in Thomas H. Karas's writing Global Climate Change and International Security. He explains the effects of environmental degradation from climate change are closely related to states' ability and intention to protect themselves from threats coming from abroad. This attitude of "self-defense" can lead to conflict or even escalate to armed hostilities and war. $\mathrm{He}$ also points out that increasingly intense competition for natural resources affected by climate change effects could exacerbate existing conflicts or even start new ones (Karas, 2003) bringing together a variety of external experts with Sandia personnel to discuss "The Implications of Global Climate Change for International Security." Whatever the future of the current global warming trend, paleoclimatic history shows that climate change happens, sometimes abruptly. These changes can severely impact human water supplies, agriculture, migration patterns, infrastructure, financial flows, 
disease prevalence, and economic activity. Those impacts, in turn, can lead to national or international security problems stemming from aggravation of internal conflicts, increased poverty and inequality, exacerbation of existing international conflicts, diversion of national and international resources from international security programs (military or non-military.

The reality of modern international security structure influenced by climate change was also noted in The Warming War: How Climate Change is Creating Threats to International Peace and Security by Kirsten Davies and Thomas Riddell. They introduced the term "Warming War" as the word they used to describe the reality in which the effects of climate change have endangered global security stability. They explain that climate change can directly or indirectly impact the security vulnerability, especially in developing countries and Small Island Developing States (SIDS) (Davies \& Riddell, 2017).

After understanding the impact of climate change can potentially cause cross-border/international conflict, what form of security threats that the impact of climate change generates? A report from the High Representative and the
European Commission to the European Council Climate Change and International Security explained at least seven potential threats presented by the impacts of climate change:

“(1) conflict over resources,

(2) economic damage and risk to coastal cities and critical infrastructure, (3) loss of territory and border dispute, (4) environmentally-induced migration, (5) situations of fragility and radicalization, (6) tension over energy supply and (7) pressure on international governance" (Council of the European Union \& European Commission, 2008).

The report also emphasized the primary role of climate change as an agent of "threat multiplier" in which climate change gives a more indirect causal dimension to security threats (Council of the European Union \& European Commission, 2008). This argument focused on the role of climate change, which is preferred to be seen as encouraging the acceleration of pre-existing instability. Furthermore, the threats posed by climate change are humanitarian (human security) aspects and inter-state political and military security risks. 
Besides, an article wrote by Jurgen Scheffran on Climate Change and Security also describes fourdimensional factors of security threats arisen from the impacts of climate change; (1) degradation of water sources, (2) food insecurity, (3) natural disasters, and (4) environmental migration (Scheffran, 2008). In addition to emphasizing the potential of climate change as a "threat multiplier of instability," this article also includes a historical explanation of the relations between climate change (or temperature) and conflict. According to this paper, temperature changes are always followed by decreasing agricultural production and intensifying warfare's frequency resulting in the collapse of various forms of ancient civilization and modern political revolutions (Scheffran, 2008).

Based on this literature review, several propositions regarding relations are between climate change impacts on international conflict. First, these propositions are the global nature of the impacts of climate change that has resulted in cross-border/international dimensions of conflict and the accompanying security instability. Therefore, climate change impacts can lead to tensions and conflicts between countries. Second, the effect of climate change does not directly result in security disturbances but instead must be translated into a series of threats, which generally include; (1) natural resources, (2) agriculture, (3) natural disasters, (4) migration flows and population movements, and (5) territorial existence. Third, the impact of climate change can be a threat multiplier agent that will encourage the escalation of potential vulnerabilities and preexisting conflicts.

\section{DISCUSSIONS AND FINDINGS}

\section{Climate Change in the Nile}

A report in 2007 stated that many rivers and lakes in Africa are hotspots of climate change, where these water sources are particularly vulnerable to the possible impacts caused by changing climate patterns (Intergovernmental Panel on Climate Change, 2007). Due to the Nile's geographical location and crucial role for the surrounding population, climate change generates more impact on the river. Indicators of climate change generally seen in the Nile case include temperature, precipitation, and evapotranspiration.

Current climate change trends have shown a significant 
temperature rise in Egypt. The data show a $0.5^{\circ} \mathrm{C}$ increase in the average annual temperature per decade during 1983-2013. Moreover, the daily minimum temperature in Egypt has also continued to rise since 1960. Future trend predictions indicate a $2-3^{\circ} \mathrm{C}$ rise in mean annual temperature in 2050, with a drastic increase will hit during the summer and in the barren southern area (United States Agency for International Development, 2018). This trend also occurs in Ethiopia as a place where headwaters of the Nile (Nile Blue), Lake Tana, are located.

Furthermore, as happened in Egypt, the average temperature in Ethiopia (including Lake Tana) has also increased due to the climate change process. The report shows a $0.1^{\circ} \mathrm{C}$ increase in the minimum temperature per decade and a 0.25 0.37 in the maximum temperature per decade. The mean annual temperature across Ethiopia also experiences a rise of $0.28^{\circ} \mathrm{C}$ per decade (Zeleke \& Damtie, 2017) regression and wavelet analyses were used to investigate the trend, frequency and intra-annual variability of climate over the Abay (Blue Nile.

Another indicator of the climate change process is precipitation.
Current climate change trends have shown the decreasing precipitation rate has reached $2.76 \mathrm{~mm}$ per month since 1960 (Ministry of Foreign Affairs of the Netherlands, 2018). Future projections even show Egypt in 2050 will experience a growing decrease in rainfall, with coastal areas predicted to decrease by $7 \%$ and the central to southern regions by $9 \%$ (World Bank, n.d.-a). The precipitation rate is also an essential factor in Ethiopia because the primary water source in Lake Tana comes from rain. The average annual rainfall in Lake Tana can reach 1280 $\mathrm{mm}$ (Abebe et al., 2017)regression and wavelet analyses were used to investigate the trend, frequency and intra-annual variability of climate over the Abay (Blue Nile. However, along with the growing process of climate change, the variability of the rain cycle in Lake Tana is challenging to predict due to El-Nino and $\mathrm{La}$ Nina's presence caused by the Pacific Ocean's warming temperatures.

The rising temperatures along the Nile River basin due to climate change have increased evaporation and evapotranspiration. The rising of surface temperature along the Nile has increased evapotranspiration, which is expected to reach $9 \%$ by 2050. Studies suggest an increase 
in evapotranspiration by $4 \%$ could lead to an $8 \%$ potential reduction in Blue Nile's water flow and $11 \%$ at Lake Victoria (United Nations Environment Programme, 2013). Evapotranspiration will severely hit water supplies in Nile's huge headwaters, such as the African Great Lakes and Lake Tana and arid regions generally found in Egypt and Sudan.

The presence of various key indicators of climate change (temperature, precipitation, and evapotranspiration) is predicted to affect water availability in the Nile River. Statistical data predicts that there will be a significant decrease in annual water flow in the Blue Nile River after 2050. The decline is maximally predicted to reach $-50 \%$ (United Nations Environment Programme, 2013). The reduced water flow in the Blue Nile will positively impact decreasing Nile River water's quantity in downstream areas such as Egypt and Sudan. In addition to reducing the amount of water, climate change can also increase interannual variability. Nile water flow will experience extreme fluctuations characterized by the growing number of "extreme years" in floods and prolonged drought (Ministry of Foreign Affairs of the Netherlands, 2018).
Security Threats of Climate Change in the Nile

The increase in capacity reduction and inter-annual variability flow in the Nile because of the climate change process potentially creates various security threats, especially for downstream countries that have been very dependent on the river. Changing the flow pattern will significantly affect the emergence of Egypt's risks, which mainly includes water security, food availability, and national economic stability issues.

Rising temperatures and reduced rainfall in Egypt can increase the Egyptian population's water demand toward the Nile River. However, the river is already affected by climate change in which future projections show that there will be a significant decrease in its water capacity. The extended demand without an increase in supply will harm the water balance and endanger Egypt's water security. Damage to Egyptian water balance will significantly affect the agricultural sector, where it consumes at least $80 \%$ of the national freshwater resources (United States Agency for International Development, 2018).

Current Egypt's agricultural conditions also exacerbate the threat to water availability for the agriculture sector. The main crops, 
such as cotton, wheat, rice, corn, and berseem, contribute $80 \%$ of the total land area and around $60 \%$ of the total water consumption in Egypt's agricultural sector. Rice plantation in Egypt alone already absorbs $15 \%$ of total water consumption in the agricultural sector (Zeidan, 2013). Given the diminishing availability of Nile water, water-hungry plants such as rice in the Egyptian population's cereal structure will threaten national food availability. Moreover, Egyptian food availability will also be significantly affected by the current traditional method in domestic agriculture.

The potential impact of climate change on the Nile will also affect the Egyptian economy's stability, which depends on agricultural production. The agriculture sector contributes $11.7 \%$ of GDP and absorbs $25.8 \%$ of the national workforce (Central Intelligence Agency, n.d.). In addition to reducing Nile water flow, climate change is also predicted to reduce the fertile land area in Egypt, which is indeed located in the basins and delta of the Nile. The reduced flow of the Nile and the depletion of fertile land will lead to a decline in agricultural yields that can hurt domestic economic conditions. Besides, the reduced availability of Nile water can affect the textile industry's production, which generally requires an abundant water supply. The decline in the textile industry's production output due to water availability issues will significantly impact the Egyptian economy, where the industry contributes to a quarter of Egypt's non-oil and gas exports and absorbs a large amount of labor.

Vulnerability factors also exacerbate Egypt's security threats mentioned above; 1) increasing population and 2) extensive poverty. These two vulnerability factors are not only found in Egypt (internal vulnerability) but can also be found in Ethiopia (external vulnerability).

First, Egypt experienced a steady population growth of around $2 \%$ per year, which made Egypt's population growth in 1980-2008 reached $41 \%$. The 2017 data stated that Egypt's population reached 97.55 million people and is also the country with the largest North Africa population (World Bank, n.d.-b). Ethiopia also showed steady growth, but even at a tremendous rate of $2.5 \%-3 \%$ per year. This substantial growth rate has made Ethiopia's population have surpassed Egypt since 2005, and in 2017, it reached 105 million people or the largest between Nile basin countries (World Bank, n.d.-b). 
Second, Egypt's poverty rate is still tremendous which 2016 data indicated that there are still $27.8 \%$ of Egypt's population (or around 26.6 million people) living below the poverty line (Central Intelligence Agency, n.d.). This poverty issue also happens in Ethiopia. Although Ethiopia shows rapid economic growth (around 10\%), this figure becomes difficult to translate when population growth increases significantly. Data from 2015 show $23.5 \%$ of the population below the national poverty line and $30.8 \%$ of the people below the global poverty standard (World Bank, n.d.-b). The presence of these two vulnerability factors will potentially increase the threat of climate change security in the Nile, where these two factors will require the availability and demand of large amounts of water in the form of irrigation and energy supply.

Climate Change as a "Threat Multiplier" of the Egypt-Ethiopia Conflict

In the end, all the security threats derive from the impacts of climate change are translated under the role of climate change as a threat multiplier or as an agent of reinforcing/escalating existing security conflicts. In the Nile case, the actual conflict had long occurred between basin countries related to river flow management. This conflict's historical origin originated from two international treaties, which became the fundamental basis of the Nile flow's current management, the 1929 Agreement and the 1959 Agreement.

The 1929 Agreement or officially known as the Exchange of Notes Regarding the Use of Waters of the Nile for Irrigation Purposes, was an agreement between Egypt and the United Kingdom (at that time represented its colonial state, Sudan) which gave Egypt and Sudan the right to receive 48 and $4 \mathrm{bcm}$ from the flow of the Nile annually. Besides, this agreement also gave Egypt exclusive rights to oversee the Nile's flow upstream and to veto any construction projects along the Nile, threatening their interests (Zeidan, 2013). After Sudan gained its independence in 1956, the 1929 Agreement began to be reviewed. After various bargaining and negotiation processes, two countries approve the 1959 Agreement or "Agreement on Full Utilization of the Nile Waters between Egypt and Sudan." This agreement determines that the annual quantity capacity of the Nile is set at $84 \mathrm{bcm}$ in which all will be allocated to Egypt and Sudan as much as 55.8 and 18.5 
$\mathrm{bcm}$ respectively, leaving only ten $\mathrm{bcm}$ for the potential of water lost through evaporation and other natural factors (Carles, 2006).

These two agreements ensure the dominance of downstream countries, especially Egypt, in maintaining its hydro-hegemony over the Nile River. The pattern of power relations between the Nile basin states was always regulated to benefit Egypt and harm the upstream countries' interests, especially in this case, Ethiopia. The source of Egyptian power in maintaining this "imbalance" of power relations comes from its structural capability, bargaining power, and ideology influence (Carles, 2006). As Ethiopia became increasingly concerned about the economic potential of the Nile (and followed by its growing economic capability), the country began to dare "to revise" Egypt's status quo in the Nile management. Ethiopia (with other upstream countries) started to emphasize their utility rights, ask for more equitable distribution and oppose Egypt's natural and historical claims to the Nile. The latest and "hardest" Ethiopian resistance is constructing the Great Renaissance Ethiopian Dam (GERD) project at $500 \mathrm{~km}$ southwest of Addis Ababa and close to the Ethiopian-Sudan border.
Ethiopia's economic development ambitions are driven by the GERD project to meet domestic electricity needs while exporting more to neighboring countries. With GERD's existence, Ethiopia wants to become a significant electricity exporter, especially in the Horn of Africa. The GERD construction project officially began in 2011 and is planned to be the largest dam in Africa, with $1800 \mathrm{~m}$ in length and $170 \mathrm{~m}$ in height. Inside the dam, there will be a $150 \mathrm{~km} 2$ reservoir with $67 \mathrm{bcm}$ water capacity. Two power stations will be installed on both sides of the river with electricity capacity reaching $6000 \mathrm{MW}$, or it can produce around $15000 \mathrm{GW}$ per hour per year (Harb, 2019).

The ambition of Ethiopia's economic development through GERD is what has heightened tensions between Ethiopia and Egypt. Egypt is worried that the GERD project will threaten their historical rights and eventually lead to its survival affairs as Egypt relies heavily on the Nile flow. The main short-term problem lies in the time of the first reservoir filling, in which Egypt (and Sudan) will be very vulnerable to experiencing water shortages during this period. Initially, Ethiopia planned the time to be around three years, drastically 
reducing the Nile water supply to Egypt. The Egyptian side sharply criticized this plan, and they countered with a new proposal citing minimum time to be around seven years. However, at the time of writing in 2019, there was still no clarity regarding the agreed time of first reservoir filling and the negotiation deadlock between the two parties (Shay, 2018).

Egypt is in the long-term worried about the decline in water capacity they receive from the Nile along with the construction of GERD. The decline potentially threatens Egypt's water security in which they describe as a matter of national security (Swain, 1997). Therefore, Egypt is trying hard to keep the GERD project from threatening the status quo they have enjoyed so far. To fulfill this goal, the first path taken is through diplomatic negotiations between Egypt and Ethiopia. However, talks seem to be still running in place or even deadlocked, along with the opinion incompatibility on underlying issues such as the appointment of independent consulting agency and other parties such as the World Bank (Shay, 2018). Both parties even blame each other for being the ones who slow down the negotiation process.
The deadlock of diplomatic negotiations can lead to escalating conflicts and more dangerous security tensions. It happens because the Nile water is a sensitive issue involving Egypt's national security problems. When viewed from the historical context, there has long been a bitter conflict between Egypt and Ethiopia concerning the Nile. These cold conflicts generally include official verbal expressions (both light and stiff), diplomaticeconomic feuds, and even politicalmilitary hostilities (Carles, 2006). Although there are various forms of conflict, there have not been any small or large-scale military operations between the two.

However, the tension between the two can potentially escalate along with the Ethiopian insistence on GERD construction. Several recent military showcase actions from the Egyptian military, such as forming the new South Fleet in the Red Sea in 2017, reinforced their most sophisticated warships, "Gamal Abd al-Nasir" and "Ahmad Fadil". The Egyptian Navy Commander explained that this fleet is employed when "regional dynamics developments" leading to the threat of "Egypt's national security". This military showcase was even exploited as Egypt's basis for 
bargaining so that Ethiopia would resume their negotiations (Lawson, 2017). Besides, Egypt also has closer cooperation with Ethiopia's neighboring rival countries such as Uganda, South Sudan, and Eritrea. Egypt is claimed to have helped these countries to launch armed conflict operations with Ethiopia (Eritrea) and Sudan (South Sudan), which supports Ethiopia (Lawson, 2017). Therefore, it can be observed here that the conflict over the management of Nile potentially grows towards an armed conflict that not only involves the two but also includes other regional players, which will automatically threaten regional security stability.

How does climate change play a role as a threat multiplier of existing conflict between Egypt and Ethiopia? The previous explanation has shown that climate change has brought rising temperatures, declining precipitation, and increasing evapotranspiration, which led to decreasing water capacity and inter-annual variability in the Nile. The reduced water supply of the Nile will make Egypt enhance attention to efforts that can reduce their water supply from the Nile, with the GERD project stands as their present biggest threat. Egypt's focus will also develop massively as the population grows, and poverty rates are still high. The more considerable attention of Egypt can result in Egypt's earnest desire to maintain its water security even to the extent that many people fear the outbreak of the Water War. Although many people oppose this argument but seeing the reality that the Nile is one of the hotspots of climate change and coupled with the absence of comprehensive international water management, all possibilities are still counted and must be undertaken cautiously. The following concept map can help explain the various idea connections in this paper.

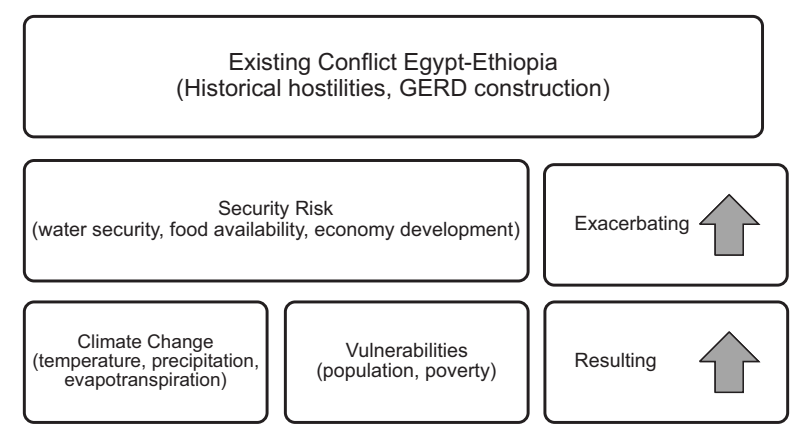

Diagram 1. Relations Between Climate Change and Security in Nile River 


\section{CONCLUSION}

One of the climate change hotspots is the Nile River and its surrounding region. Climate change in the Nile can be seen from the rise in temperature, a decrease in rainfall, and an increase in evapotranspiration. Coupled with vulnerability factors (population and poverty), the phenomenon of climate change can result in various forms of security threats that involve water security, food availability, and economic development. Therefore, the diminished water flow in the Nile as an impact of climate change will lead to growing Egypt's awareness of projects that can decrease their water supply from the Nile with the GERD remains as their current most significant risk. An enormous Egypt's attention can result in the country's earnest desire to maintain its water security, leading to the instability of security relations between Egypt and Ethiopia and even escalates to other regions.

\section{BIBLIOGRAPHY}

Abebe, W. B., G/Michael, T., Leggesse, E. S., Beyene, B. S., \& Nigate, F. (2017). Climate of Lake Tana Basin. In K. Stave, G. G. Yemer, \& S. Aynalem (Eds.), Social and Ecological System: Dynamics Characteristics,
Trends, and Integration in the Lake Tana Basin, Ethiopia (1st ed., pp. 51-58). Springer International Publishing. https://link.springer.com/ book/10.1007/978-3-31945755-0

Carles, A. (2006). Power Asymmetry and Conflict over Water Resources in the Nile River Basin: the Egyptian Hydro-hegemony. King's College London.

Central Intelligence Agency. (n.d.). The World Factbook: Egypt. Retrieved December 11, 2019, from https://www.cia.gov/ library/publications/the-worldfactbook/geos/eg.html

Council of the European Union, \& European Commission. (2008). Climate Change and International Security: Paper from the High Representative and the European Commission to the European Council. https:// doi.org/10.2860/50106

Davies, K., \& Riddell, T. (2017). The Warming War: How Climate Change is Creating Threats to International Peace and Security. The Georgetown Environmental Law Review, 30(1), 47-74. https://www.law.georgetown. edu/environmental-lawreview/wp-content/uploads/ 
sites/18/2018/05/30-1-TheWarming-War-How-ClimateChange-is-Creating-Threatsto-International-Peace-andSecurity.pdf

Harb, I. K. (2019). River of the Dammed. Foreign Policy. https://foreignpolicy. com/2019/11/15/river-of-thedammed/

Intergovernmental Panel on Climate Change. (2007). Climate Change 2007: Impacts, Adaptation and Vulnerability (M. Parry, O. Canziani, J. Palutikof, P. van der Linden, \& C. Hanson (eds.); 1st ed.). Cambridge University Press. https:// doi.org/10.1177/108602661 1419862

Intergovernmental Panel on Climate Change. (2018). Summary for Policymakers of Global Warming of $1.5^{\circ} \mathrm{C}$ : An IPCC Special Report (V. MassonDelmotte, P. Zhai, H. O. Pörtner, D. Roberts, J. Skea, P. R. Shukla, A. Pirani, W. MoufoumaOkia, C. Péan, R. Pidcock, S. Connors, J. B. . Matthews, Y. Chen, X. Zhou, M. I. Gomis, E. Lonnoy, T. Maycock, M. Tignor, \& T. Waterfield (eds.)). https:// report.ipcc.ch/sr15/pdf/sr15_ spm_final.pdf\%0Ahttp://www. ipcc.ch/report/sr15/
Karas, T. H. (2003). Global Climate Change and International Security. https://prod-ng. sandia.gov/techlib-noauth /access-control.cgi/2003/ 034114.pdf

Lawson, F. H. (2017). Egypt versus Ethiopia: The Conflict over the Nile Metastasizes. The International Spectator, 52(4), 129-144. https://doi.org/10.10 80/03932729.2017.1333272

Levine, S., Peters, K., \& Fan, L. (2014). Conflict, Climate Change and Politics: Why a Techno-centric Approach Fails the Resilience Challenge (Issue February 2014). https:// www.odi.org/sites/odi.org.uk/ files/odi-assets/publicationsopinion-files/8825.pdf

Lippert, T. H. (2016). NATO, Climate Change, and International Security: A Risk Governance Approach [Pardee RAND Graduate School]. https://doi. org/10.7249/rgsd387

Ministry of Foreign Affairs of the Netherlands. (2018). Climate Change Profile: Egypt. www. government.nl/foreign-policyevaluations

Newman, N. (2019). How climate change could impact the Nile. Eniday. https://www.eniday. 
com/en/human_en/climatechange-impact-nile/

Scheffran, J. (2008). Climate Change and Security. Bulletin of the Atomic Scientists, 64(2), 19-25. https://doi. org/10.2968/064002007

Schlanger, Z. (2019). 250 million people rely on the Nile for water that may not exist by 2080. Quartz. https:// qz.com/1709757/climatechange-threatens-the-nilescritical-water-supply/

Shay, S. (2018). The "Renaissance Dam" Crisis. Herzliya Conference Papers. https://www.idc.ac.il / en/research/ips / 2018 /documents/shaulshayrenais sance damen22.4.2018a.pdf

Swain, A. (1997). Ethiopia, the Sudan, and Egypt: The Nile River dispute. The Journal of Modern African Studies, 35(4), 675694. https://doi.org/10.1017/ S0022278X97002577

United Nations Climate Change Secretariat. (2019). Climate Action and Support Trends 2019. https://unfccc.int/sites/default/ files/resource/Climate_Action_ Support_Trends_2019.pdf

United Nations Environment Programme. (2013). Adaptation to Climate-change Induced
Water Stress in the Nile Basin: A Vulnerability Assessment Report. https://na.unep.net/siouxfalls/ publications/Nile_Basin.pdf

United States Agency for International Development. (2018). Climate Risk Profile: Egypt. https://www. climatelinks.org/sites/default/ files/asset/document/2018_ USAID - ATLA S - Project_ Climate-Risk-Profile-Egypt.pdf Vogler, J. (2014). Environmental Issues. In J. Baylis, S. Smith, \& P. Owens (Eds.), The Globalization of World Politics: An Introduction to International Relations (6th ed., pp. 341-356). Oxford University Press.

World Bank. (n.d.-a). World Bank Climate Change Knowledge Portal: Egypt. Retrieved December 10,2019, from https:// climateknowledgeportal. worldbank.org/country/egypt

World Bank. (n.d.-b). World Bank Open Data. Retrieved December 16, 2019, from https://data.worldbank.org

Zeidan, B. A. (2013). Water Conflicts in the Nile River Basin: Impacts on Egypt Water Resources Management and Road Map. https://doi.org/10.13140/ RG.2.1.4414.3849 
Zeleke, T. T., \& Damtie, B. (2017). Temporal and Spatial Climate Variability and Trends Over Abay (Blue Nile) River Basin. In K. Stave, G. G. Yemer, \& S. Aynalem (Eds.), Social and Ecological System: Dynamics Characteristics, Trends, and Integration in the Lake Tana Basin, Ethiopia (1st ed., pp. 59-75). Springer International Publishing. https:// doi.org/10.1007/978-3-31945755-0_6 